\title{
Transition to Circular Economy and Management of Public Services of General Economic Interest ${ }^{1}$
}

\author{
Sandra Antoniazzi \\ University of Rome 2 "Tor Vergata", Italy \\ sandra.antoniazzi@uniroma2.it \\ https://orcid.org/0000-0003-1365-8082
}

Received: 10.08.2021

Revised: 25. 9. 2021

Accepted: 25.11 .2021

Published: 29. 11. 2021

\section{ABSTRACT}

Purpose: The aim of this paper is to clarify the topic of the transition to Circular Economy, an expression of the European "Green New Deal", which has several application consequences for the SGEI sector.

Approach: The approach consists of examining the European policy framework, the most relevant aspects of the transposition of the 2018 waste directives for the domestic system, the new measures for local authorities and users, and the new "purpose" of the utilities industries based on sharing and environmental solutions.

Findings: The study highlights the need for several practical adjustments in the implementation of Circular Economy: the necessary technological innovation requirements for industrial production, reforms of the national legal framework, and an inevitable wider cultural evolution. Publications concerning the transition to Circular Economy in relation to public services of the general economic interest sector are not numerous in law literature. Most of the existing documents and communications are provided by the European Commission and the analyses are based mainly on the guidelines of the new green policy and the specific EU legal framework.

Academic contribution to the field and originality/significance/value: The paper adds to existing research and focuses mainly on legal studies and the wider consequences for national utility policy and companies' business plans, on the role of local public authorities having direct powers that need reforms, and the position of consumers.

Keywords: circular economy, transition, services of general economic interest, management, innovation in law.

1 This is the revision of the paper submitted to the IIAS 90ths Anniversary Conference. 


\section{Introduction}

The European Circular Economy model and 2018 regulations on waste are not limited to this sector but anticipate the recent and wider European policy of the Green New Deal (2019/2020). This model imposes incisive measures on economic activities and the management of public services of general economic interest for environmental sustainability. There are inevitable direct consequences for competences of local authorities, the industrial policy of service management companies and for citizens-users.

The new paradigm of the "Circular Economy" goes beyond the boundaries of the administrative action of mere waste management to protect the environment and includes the entire industrial process of design and production of goods. It becomes also an instrument of industrial policy, capable of guiding and attracting investments, generating value; this model that cannot be confined in the scope of the environmental protection, but necessarily includes the social, educational and financial profiles inherent in the overall redefinition of European industrial policy.

Therefore, the efficient use of resources is necessary for environmental reasons to reduce their consumption and the resulting ecological deficit, so the Circular Economy becomes, at the same time, an objective of industrial plans and the competitive market.

Law innovations on the Circular Economy coming from the European Union lead to address the problems of sustainability beyond simple conservation and the aim is not only to invest more in environmental protection, but to push towards regeneration for which, in short, the environment is characterized as a real driving force for economic development. Circular Economy programming is subject to continuous study and adaptation for gradual and efficient solutions (European Commission, 2019-2020).

It is so necessary to overcome the traditional model of relationship between business and consumers; recently, environmental protection objectives involving businesses, users and the sector regulator have been added, under the EU law and soft law. In this context, we examine the Italian legal measures and the possible role of public and private subjects involved in the gradual implementation of the Circular Economy in the perspective of management solutions by means partnership, public-private companies of adequate size.

The main objective of this article is to highlight the complex framework of the various issues related to the European Green New Deal and the Circular Economy, according to an interdisciplinary reading between European and national (Italian) administrative and economic law, in order to identify a rational solution. The consequent objectives concern the clearest possible reconstruction of the issues that concern not only the specific sector of waste management, but more generally the new political and "cultural vision", in the strict sense of the word, of the economy and the exercise of productive activities by businesses in a sustainable, shared and modern vision, as a direct consequence of the climate change and the generalised economic crisis. 


\section{Methods}

The research method adopted is comparative with the aim of identifying the links between different institutions of administrative law and economics law in the EU and Italian systems. The article examines the legal positions not only of public bodies, but also of businesses and consumers, all of whom are directly involved in the provision of public services of general economic interest.

Hence, the most relevant questions: are the public services be reconnectable to the use of economic goods that can also be configured as common goods? what are the consequences of the new European environmental policy and the transposition of the 2018 European directives "Circular Economy Package" on the internal system? And on the Italian one? also for the search of a clear definition of the concept of "Circular Economy".

Finally, we intend to investigate the very interesting topic of the effects of the new policy and the specific discipline towards the "purpose" contained in the statutes of the public service companies, which acquire a strategic role in the implementation both for the contribution of knowledge, technologies and of funding, and the use of "Green Finance" instruments to support significant investments for innovation for the benefit of the community and not only in the perspective of profits. This complex context should be interpreted in the light of new forms of collaboration with local public bodies and citizen-users.

\section{Public Services of General Economic Interest and Common Goods}

Public services of general economic interest (such as water service, energy, waste management) relate directly to resources that can be framed in the concept of common goods (commons) (Felber, 2012; Passalacqua, 2015; Bombardelli, 2016; Tirole, 2017; Simonati, 2018) which we could qualify also as circular goods, in the current economic and environmental emergency context and considering the objective of reusing resources. Moreover, the perspective widens if we consider subjects involved in management and reuse, public and private sectors: the community of citizens, local authorities, businesses. These categories must not be considered in opposition, but in collaboration, differentiating the roles and stages of participation.

The Circular Economy could, in fact, favor the emergence of participation, as it involves an increasingly active role of the individual components of the community. However, it is necessary to clearly distinguish this model from the "collaborative economy" which can become a social economy, based on social relations and duties of solidarity. The "economy of society" is clearly different and can be traced back to a context in which individuals are linked by a general interest that establishes also a subjectively public dimension that goes beyond the rights and interests of individuals and concerns the collectivity (Ostrom, 2015; Passalacqua, 2019). 
The European environmental policy and the discipline introducing the new waste management and methods of production-management-reuse of waste - directives (EU) n. 849-850-851-852/2018 "Circular economy package"- have a direct influence in national systems, which will implement these rules.

The commons could also emerge in the waste sector, if we consider that the reuse of materials has first and foremost environmental consequences with obvious community interests and not only economic benefits.

So the Circular Economy points towards new objectives and methods for public services of general economic interest and new solutions for the organisation and the "purpose" of management companies considering citizens interests connected to environment.

\section{The 2018 European Directives on Waste}

The first recital of directive 2018/851/EU states that waste management in the EU should be improved and transformed into sustainable management of materials to safeguard the quality of the environment, to protect human health, to ensure the prudent, efficient and rational use of natural resources and to promote the principles of the Circular Economy (Massarutto, 2019; Munari, 2019; Simone, 2019; Verri, 2019; Bianchi, 2018, Bompan - Brambilla, 2018; Scarpellino, 2018; Lacy, 2016 and 2015; Cerrina Feroni, 2014; Cartei 2013).

Despite other different references to the Circular Economy, in this directive just mentioned and in others transposed by the Italian legislative decrees, there are no further definitions or contents useful for the interpreter. In addition, there are obvious problems of adaptation of our legal system that are not solvable only with the transposition of the 2018 directives, if we consider the legal schemes of administrative and economics national law and the competences of the public bodies involved are obsolete. More generally, the implementation of the Circular Economy could be an opportunity to innovate public legal instruments applicable to the economy.

It is therefore necessary to refer to the various documents and directives that accompanied the birth and the diffusion of the idea of the Circular Economy in Europe. At first the "European Union Action Plan for the Circular Economy" (December 2, 2015) by which the European Commission approved and proposed the package of directives for the transition from the linear and traditional economy to the Circular Economy. The action plan defines 54 measures to "close the circle" of the product life cycle: from production and consumption to waste management and the secondary raw materials market. In addition, it identifies five priority sectors to accelerate the transition along their value chain (plastics, food waste, essential raw materials, construction and demolition, biomass and biological materials).

Another relevant document of the European Commission is the "European strategy for plastics in the Circular Economy" (16 January 2018) and the directive 2019/904/EU on single-use plastics (also called SUP directive, Single Use 
Plastics) approved on 21 May 2019. The directive aims to prevent and combat marine litter and sets stricter rules for the types of products and packaging that are among the ten pollutants most often found on European beaches. The new rules prohibit the use of certain disposable plastic products for which there are alternatives on the market. The European Commission also approved on 12 October 2018 the document "A sustainable bioeconomy for Europe: strengthening the link between economy, society and the environment" with the aim of improving and increasing the sustainable use of renewable resources in order to addressing climate change and promoting sustainable development.

This first phase of the European Union ended with the "Reflection paper towards a sustainable Europe by 2030 (European Commission, 2019)" by which the Junker Commission ended its mandate by launching the debate on the future of Europe and on the preparation of the Agenda strategy 2019-2024 of the European Union and the priorities of the European Commission. The reflection paper focuses on the transition to sustainability and includes the transition from a linear traditional economy (extract, produce, throw away) to a Circular Economy, the correction of imbalances in our food system, energy of the future, buildings and mobility (D'M. Coffman et al., 2020). The growing availability and affordability of various materials and products have simplified our lives and contributed to raising the standard and quality of life in the EU.

We can identify a second phase of the Circular Economy that has started with the new European Commission chaired by Ursula Von der Leyen who claimed to aim for World leadership on sustainable development and on 11 December 2019 presented the Green New Deal (Barbier, 2019; Aronoff et al., 2019; Atil Asici and Bünül, 2012; Baribier, 2010). Through this new plan, the European Commission gives a significant boost to the green transition and indicates a detailed stringent roadmap and actions for transition to the Circular Economy, stimulating the efficient use of resources, halting climate change, counteracting loss of biodiversity and reduce pollution.

The European Green Deal affects all sectors of the economy, with a commitment to propose targets for separate collection, waste reduction, reuse and recycling, as well as other specific actions such as extended producer responsibility in priority sectors such as commercial waste, textiles, plastics, electronics, construction and food. The investment plan is impressive and is divided into three dimensions: mobilize at least $€ 1,000$ Billion of sustainable investments over the next ten years and incentives to unlock and redirect public and private investments, making sustainable finance a pillar of the financial system. The Commission will provide support to public authorities and promoters (private subjects, private or mixed companies) in the planning and implementation of sustainable projects.

As part of the New Green Deal, President Von der Leyen announced the European strategy that was (and will be) expressed into many acts and plans (European Commission, 2020) and today the most advanced documents on 
environmental sustainability come from the European Union, which has become the politically and legally most committed entity in this direction.

All these documents mentioned above are crucial for the useful elements of in-depth analysis of the new European environmental policy, but there is a significant problem of gradual and effective understanding of the common objectives in the internal legal systems, especially if we consider that not only legal adjustments are required, but a broader cultural evolution of the industrial sectors and, in particular, of the industry of public services of general economic interest and technological innovation strategies. Thus, the reforms of the disciplines for the different sectors is only one aspect, since more widely the innovations must be introduced in national policy choices and in the objectives of industrial plans.

\section{The European Environmental Policy and Related Discipline}

Directives on waste and the Circular Economy are also law in Italy with the legislative decrees of 3 September 2020, п.116, п. 118, п. 119 and n. 121, published respectively on 11, 12 (second and third) and 14 September 2020. These are the legislative decrees transposing the European package of measures on the Circular Economy that amended the before directives (19942012) on waste and landfills.

The topic that we want to deal with is the definition and contents of the Circular Economy, repeatedly referred to also with particular emphasis in Italian legislative decrees, to understand general rules and measures.

Regarding purposes of waste management law, "the effectiveness and the tools that constitute the fundamental elements" have been introduced with art. 1, par. 1 of the legislative decree n. 116/2020 "for the transition to a Circular Economy" (new art. 177, par. 1, legislative decree n. 152/2006). In the subsequent paragraph 7 it declares to want to "proceed towards a Circular Economy with a high level of resource efficiency" (new art. 181, par. 4, legislative decree n. 152/2006). Other references are in art. 2 of the same legislative decree n.116/2020 which introduces the national program for waste management which must contain "the identification of homogeneous flows of functional and strategic waste for the Circular Economy (new art. 198-bis, par. 3, letter g, legislative decree n. 152/2006" and "the definition of a national plan of communication and environmental knowledge on waste and Circular Economy (new art. 198-bis, par. 3, letter h, legislative decree n. 152/2006)". The following article 3 of the same legislative decree n. 116/2020 aims to "favor the transition towards a Circular Economy (new art. 218, par. 2, and 237, par. 1, legislative decree n. 152/2006)". This purpose is also reiterated in art. 1 , paragraph 1, letter a), of legislative decree n. 121/2020 which amends art. 1, раг. 1, of the legislative decree n. 36/2003 on waste landfills. 
Principles of the new regulation on waste represent the first concrete objectives that our legal system sets for the transition to the Circular Economy; they are strategic by both Italy and the European Union, as later they will say. This framework involves the regulated market for services of general economic interest (Bruti Liberati, 2010) that include the waste, water and energy sectors and thus the broad scope of the Circular Economy. Therefore, market rules will also have to consider the generalized innovation policy. Moreover, the approach does not only concern waste management, but is more general as it relates to the water and resources of all productive activities that must be gradually planned in ways that are compatible with the environment and in order to combat climate change.

The Italian discipline is articulated, so we consider only some general aspects that seem to characterise it and constitute the starting point for Circular Economy strategies. The objectives of the new waste regulation "to move towards a Circular Economy" are numerous and with different deadlines from 2020; the main ones are listed in paragraph 4 of the new art. 181 of legislative decree $n .152 / 2006$. The objective is then to simplify the secondary raw materials market and, to this end, it is expected that those who use, for the first time, a material that has ceased to be considered waste and that has not been placed on the market or that is a material on the market for the first time after it ceases to be considered waste, must ensure that the material meets the requirements under the applicable legislation on chemicals and related products (new art. 184-ter, par. 5-bis, legislative decree n. 152/2006).

In order to establish itself, the Circular Economy will need a reference market, economic instruments and useful tools for its growth, which are not only the regulatory ones of the State. To the prescriptive and regulatory instruments, typical of the legal technique, the new discipline combines those of the market that are described in the new Annex L-ter to legislative decree $n$. $152 / 2006$ which contains a detailed list of possible public intervention tools in the economy and other measures for waste sectors.

There are a lot of measures, such as taxes and restrictions for landfilling and incineration of waste which incentivize prevention and recycling, leaving landfilling as a less preferable waste management option, punctual tariff schemes that burden waste producers in relation to the actual quantity of waste produced and provide incentives for the source separation of recyclable waste. The aim to reduce of unsorted waste is achievable by tax incentives for the donation of products, in particular food, extended producer responsibility schemes for various types of waste and measures to increase their effectiveness, cost-efficiency and governance, or trough deposit-refund systems and other measures to encourage the efficient collection of used products and materials, sound planning of investments in waste management infrastructure. Other schemes relate to EU funds and sustainable public procurement to encourage better waste management, the use of recycled products and materials, economic incentives for local and regional authorities, aimed 
at promoting waste prevention and intensifying separate collection, while avoiding support for landfilling and incineration.

Another important aspect of the Italian law is the extended producer responsibility (OECD, 2008), which was already contained in the "framework" Directive 2008/98/EC on waste that was implemented in domestic law by inserting art. 3, par. 1, legislative decree 3 December 2010, n. 205 and art. 178-bis of the socalled Environmental Code, legislative decree 3 April 2006, п. 152.

The Directive 2018/851/EU and the legislative decree n. 116/2020 incorporated its contents in order to internalise the end-of-life costs of the product by including them in the price of the product itself and to encourage producers, when designing their manufactured products, to take greater account of their recyclability, reusability and repairability.

The legislative decree n. 116/2020, thus modifies art. 178-bis and in general Part IV (on waste management) of legislative decree 152/2006, establishes, even at the request of a party, extended producer responsibility regimes and refers to future decrees, for each individual extended producer responsibility, the requirements and measures include the acceptance of returned products and waste remaining after the use of those products and the subsequent waste management. So financial responsibility for such activities as well as measures to ensure that any natural or legal person who professionally develops, manufactures, transforms, processes, sells or imports products (product manufacturer) is subject to extended producer responsibility. The producers pay a financial contribution so that the same covers the costs for the products that the producer places on the national market (new art. 178-ter, par. 3, legislative decree $n$. 152/2006).

Compliance with the obligations deriving from extended producer responsibility is subject to the supervision and control of the Ministry of the environment and the protection of the territory and the sea, which, after the establishment of the new National register of producers (new art. 178-ter, par. 8, legislative decree n. 152/2006) collects the data, analyzes the financial statements and carries out as a comparative analyzes, the determination of the environmental contribution, checks that the objectives are achieved and verifies the correct implementation of the new regulations (new art. 178-ter, par. 6, legislative decree n. 152/2006).

The Italian discipline is complex and certainly analytical because of many aspects of the Circular Economy; several profiles can be linked to the issue of land use containment and urban regeneration. Land consumption is an effect of the linear economy that procures, produces, consumes and disposes of and containment through reuse can only be achieved by adopting Circular Economy mechanisms that can self-regenerate (Passalacqua, 2019).

The central goal is the implementation of these measures in the context of the pandemic crisis, especially in the waste and recycling sector; however, a medium-long term strategy would be needed whose content considers the future beyond the emergency (Venier, 28 May 2020). In addition, strategies 
inevitably need financing (mainly European funds) and legal schemes to be implemented; the current instruments of the internal order for economic activities do not seem to be adequate even in a situation of "normality" for the existing forms of public intervention in the economy. Therefore, extensive reforms are necessary on the impetus of the $\mathrm{EU}$ and in implementation of European disciplines or, even better, in direct application for the need of uniformity precisely in the perspective of transition to the Circular Economy.

Finally, the Italian regulatory authority for energy, networks and the environment - Arera (Merusi and Antoniazzi, 2017; Arera and Ansa, 2020) - will certainly play an additional important role to adopt new incentive mechanisms for companies, in order to encourage the reuse of resources (water, energy, waste) and green solutions according to the rules examined. Furthermore, probably new tasks could be assigned to the European Agency for the Cooperation of Energy Regulators (ACER).

\section{The Concept of Circular Economy in Italian Law Order}

The notion and contents of the Circular Economy are present in the Ministry of economic development (MISE), decree 11 June 2020 and not in a legal act of implementation of EU law (see Italian Government documents in www.mise. gov.it, www.gov.it, www.politicheeuropee.goc.it, Zanchini and Albrizio, 2019) in fact, even if the legislative decree n. 116/2020 was hailed as a real revolution that marks the entry of the Circular Economy into our legal system, in the new Italian discipline there is no a definition, although it is repeatedly cited as the finality of the waste legislation must pursue. The purpose of supporting transition to the Circular Economy and objectives of the new discipline seems uncertain without a specific definition of the model contents.

The only normative definition is found in an annex to the Ministerial decree of 11 June 2020 aimed at the reconversion of production processes within the Circular Economy with funding for 210 million euros. According to the Annex 2 of the Ministerial decree "Circular Economy means an economic model in which the value of products, materials and resources is maintained for as long as possible, and the production of waste is reduced to a minimum".

The concept is generic and non-binding because it is not of a legislative level, but it helps to understand and confirm that the Circular Economy has a lot to do with waste and the need to manage it as a resource. To concretely understand what is meant by Circular Economy, the ministerial decree itself is in any case helpful through the indications provided to access funding.

According to the decree, industrial research and industrial development activities contribute to the introduction of innovative models aimed at the productive reconversion of economic activities within the Circular Economy relating to product and process innovations in terms of efficient use of resources and waste treatment and transformation, including the reuse of materials with a view to circular or "zero waste" economy and environmental compatibility (eco-compatible innovations). Other goals concern the systems, tools and 
methodologies for the development of technologies for water supply, rational use and sanitation and innovative technological tools capable of increasing the lifetime of products and making the production cycle more efficient and other sectors.

Furthermore, the Ministerial decree also describes in detail the areas relating to the phase of the value chain: design, production, consumption, waste management and, for example, for production innovative models referring to the procurement of resources, their use in production and the generation of waste during the entire life cycle of the product, such as the reuse of secondary raw materials or the replacement or reduction of the presence of dangerous substances for health in the materials used. For production processes are required efficient use of resources, development of technologies and innovative industrial production lines in which waste or by-products of one industry become factors of production for another. While for consumption there are innovative models, also digital platforms, product-as-a-service models, based inter alia on leasing, and subscription schemes in which manufacturers retain ownership of the product or responsibility for its performance for the entire life cycle; the sharing of products and infrastructures may be considered forms of "collaborative economy".

In this sector, the law provides measures of integration for the waste management and enhancement within the production and consumption processes, the separate collection and logistics of products and materials. In addition, rules refer to the recovery of materials from waste, production residues for reuse and recycling and to recovery and enhancement of organic waste, biomass residues and organic sludge, such as food, feed, nutrients, fertilizers, bio-based materials or chemical raw materials.

So, the legislation of 2020 is defining the Circular Economy and its contents with difficulty and delay, but there is no lack of Italian documents that address the issue since 2017. On 13 December 2017, the joint document of the Ministry of the environment, land and sea protection and the Ministry of economic development was published "Towards a Circular Economy model for Italy", with the aim of providing a general framework on Circular Economy as well as to define the strategic positioning of our Country, in continuity with the commitments adopted under the "Paris Agreement on climate change", the "United Nations 2030 Agenda on sustainable development", in the G7 and in the European Union. This document constitutes an important element for the implementation of the broader "National Strategy for sustainable development" (2 October 2017) and addresses the transition phase towards the Circular Economy and the need to rethink the waste sector ("Italian Bioeconomy Strategy", 2017).

On 14 May 2019 the Presidency of the Council of Ministers presented the update of the "National Bioeconomy Strategy" which shows that the Italian bioeconomy is ranked third in Europe, after Germany and France, with an annual turnover of approximately 330 billion euros and 2 million jobs. Italy is also second in Europe in terms of research and innovation and often the first in terms of richness in biodiversity and innovative and quality products placed 
on the market. The Italian New Green Deal was announced in the "2020-2022 Draft Budgetary Document" as a synergistic public investment plan with private sector to direct the fight against climate change, the development of the Circular Economy and the strengthening of social and territorial cohesion.

Private and mixed companies are obviously directly involved and committed; in a recent initiative (September 2020), some local public utilities companies and other economic entities (Venier and Verde, 2020) have established the "Alliance for the Circular Economy" (promoted since 2017), launching a new document the "Position Paper 2020" of intents for the implementation of circularity in Italy and a new model of sustainable development.

Therefore, in our legal system there are several normative references, documents and specific initiatives that allow us to focus on the main issues; however, the implementation of rules will certainly be difficult, especially if we consider that the innovations are part of a system that highlights several reform needs concerning administrative law (procedures and competences of public and local authorities) and intervention in the economy (Cassese, 2020; Franchini, 2020; Durano, 2018; Merusi, 2013). There are important questions about how Circular Economy innovations can be implemented through existing legal instruments, as well as the appropriate management of economic resources.

\section{The Effects of the EU Policy on the Purpose of Public Services Companies}

Technological and "cultural" innovations and green policy are also changing previous objectives, already known, promoted by EU acts; for example the Smart City (Maugeri, 2020; Antoniazzi, 22 May 2019; Favaro, 2019; Antoniazzi, 2018; Gaspari, 2018; Venier and Lucatti, 2018; Antoniazzi, 2017) model, a modern city sensitive to needs of the inhabitants for the public services offered, is towards the evolution in Circular City, as an urban context of economic and environmental sustainability in which public services are provided according to innovative criteria of adequacy and saving of resources, reduction and regeneration of waste, renewable energy solutions, integrated circular water service (water recycling), etc. (Venier, 2021). These objectives affect the production process and the relationship with customers and smart cities will play a role in the low-carbon transition by changing consumer demand for public transport instead of private vehicles.

The new industrial policy must necessarily coordinate profit objectives with the purpose of improving environmental conditions. In the context of competition, technological innovation and the adaptation to the law and guidelines of the European Union, inserted in institutions expressing a World policy (environment, climate change and emergencies) of the most advanced Countries, play a central role. The industrial plans of the service management companies are certainly conditioned by the regulatory context and by the European Green Policy, although characterised by very ambitious goals and achievable 
only gradually, which is certainly more linear than the national one, moreover based on interventions and legal schemes that are not adequate for fast innovations (Averardi, 2018).

In fact, legal schemes often conflict with reality, with the consequence that law, instead of rationally dominating it, complicates reality because it is characterised by inadequacy in the face of faster development of economics. For the national system, there are dubious issues pertain to the adequacy internal discipline and industrial policy which should (in theory) offer solutions for a gradual transition to the Circular Economy. The complexity of the objectives can only entail a necessary collaboration/participation of local bodies (holders of skills), enterprises of adequate size, citizens as customers and the Italian regulator Arera, which acquires the role of implementing the European and national transposition regulations by means specific enforcement solutions.

The public services market is currently "oriented" by the EU: the aim is the protection of environmental interests, in addition to the protection of consumers through specific disciplines for contractual relations. In Italy, the Arera adopts more advanced solutions than the incentive for renewable sources (Luisio, 2020; Galliani, 2020), such as the so-called "White certificates", negotiable energy efficiency certificates, establishing annual obligations and objectives in proportion to the quantity of distributed resources, assigned to energy distributors. The purpose of the mechanism is energy saving and in Italy it proves to be the best tool for the cost/effectiveness ratio with effects on the costs indicated in consumer payment invoices for the services provided (optimization of electricity consumption, management of smart grids). These complex systems are obviously based on the acquisition of investments in innovative technological structures, data schemes and on the participation of consumers.

\section{The Public Utilities Market and Environmental Sustainability Objectives}

In recent years, companies are constantly engaged in public promotion of their activities in the reference area as a stable and lasting model according to the latest technologies, modern methodologies consistency with environmental protection, accreditation through involvement in international institutions and associations (see Ellen McArthur Foundation, 2020) which pursue objectives of modern industrial production respecting the environment and the Circular Economy. The current trend is the search for effective collaboration in the relationship with the user; a service company not committed to environmental objectives, runs the risk of being excluded from the market and "sanctioned" by the regulator and users. Recently, an Italian multiservice company has placed on the market "green bonds" of relevant economic value for innovative projects and the most advanced management and service delivery technologies, in line with the objectives of Circular Economy and environmental sustainability (management of waste, water system resilience, water regeneration). 
The "purpose" of companies, "the reason of the existence of a company", includes environmental and socio-economic challenges with new reporting and transparency commitments in relations with users, in addition to the contractual legal relationship (Venier and Bocchi, 2019; Venier, 2018). There are various elements for a new corporate culture, considering the reflections on the business model for objectives of the United Nations Agenda 2030, the production of services, which use resources and common goods, and on contractual relations with consumers.

Adequate dimensions of the management companies are crucial for their evolution, because they know territories and shareholders are local authorities, in order to support the infrastructure of services, new management models for the regeneration of resources and sustainable and participatory development, capable of to attract funding for green solutions.

\section{Discussion: The Intricate and Gradual Path Requires Economic and Technical Resources, Reformed Skills of Local Authorities and a New Strategic Role for Public- Private Companies}

It is necessary to rethink and to reform the skills of local authorities (Pavani et al., 2019) and the measures of the regulator for a greater consideration of public-private partnership solutions and the role of utilities companies, often mixed companies (Antoniazzi, 2017). In fact, through investments for technological innovation, companies are directly responsible for transition to the Circular Economy, considering the limited public resources and the need of private investments.

There аге many questions for Italian case: do local and regional authorities have adequate means and resources to implement the new European policy? Only some Regions have adopted specific and interesting regional legislation on supporting Circular Economy, waste reduction and resource management, financing plans (see l. reg. Emilia-Romagna, 5 October 2015, n. 16 and l. reg. Toscana, 7 August 2018, n. 48).

Will the role of the Arera Authority become more relevant and need additional skills? In our system, could the administrative entities implement the EU law and policy? Especially for the regulation relating to waste management.

The overall picture of the complex objectives highlights that the participation of public authorities, private entities and mixed companies and the collaborative involvement of consumers are crucial for the concrete implementation of the new economic model (Tirole, 2017). 


\section{Green Finance and the Involvement of the European Banking System}

Another interesting consequence of the new European policy is the Green Finance and the involvement of the European banking system; we should consider green objectives of the European Centra Bank (ECB, 2019), the European Investment Bank and of the European Climate Bank. These new aims are evolving for the method from the financing of projects to the financing of companies capable of managing activities compatible with the environment.

The Regulation (EU) 18 June 2020, n. 852 is certainly the most important legal document produced by the European Union for the green transition and is on sustainable finance, a sector considered by various public and private entities to study the development of the Circular Economy (Ellen Mc Arthur Foundation, 2020).

Unlike the four directives of the Circular Economy package, this regulation gives a definition of the Circular Economy: "an economic system in which the value of products, materials and other resources in the economy is maintained for as long as possible, improving efficient use in production and consumption, so as to reduce the environmental impact of their use, minimising waste and the release of hazardous substances at all stages of their life cycle, also by applying the hierarchy of waste". The "Recital 4" is very clear: "sustainability and the transition to a safe, climate-neutral, resilient to climate change, more efficient in terms of resources and Circular Economy are fundamental to guarantee the competitiveness of the economy of the Long-term union".

The transition to a Circular Economy is one of the six environmental objectives of the regulation (EU) n. 852/2020; the others being climate change mitigation, climate change adaptation, sustainable use and protection of water and marine resources, prevention and pollution control, protection and restoration of biodiversity and ecosystems (art. 9). The Article 13 establishes the cases in which an economic activity contributes to the transition: the efficient use of natural resources, including bio-based materials of sustainable origin and other raw materials, in production, including by reducing the use of primary raw materials or by increasing the use of by-products and secondary raw materials or energy efficiency measures and resources. In addition, there are the increase in durability, repairability, the possibility of improvement or reusability of products, in design and manufacturing activities and the increase in the recyclability of products, including the recyclability of the individual materials contained therein, including by replacing or reducing the use of non-recyclable products and materials.

As mentioned, with the Green Deal the European Commission has foreseen $€ 1,000$ Billion of sustainable investments over the next ten years, while the European Council of 17-21 July 2020 has made a total of 750 billion euros available for recovery and resilience and Italy will be the country that will receive (we hope) the largest share of the Recovery fund: 208.8 billion, of which 81.4 non-repayable and 127.4 in loans. 
By means the Ministry of economic development decree 11 June 2020, which allocates 210 million for the reconversion of production processes in the Circular Economy, and the "National Recovery and Resilience Plan" 15 September 2020), the Presidency of the Council of Ministers has provided interventions for promotion of the Circular Economy and measures to increase resilience to climate change: integrated management of the water and waste cycle to improving the state of inland and marine waters, greater efficiency in the use of water resources and interventions to improve the ability of the production and agricultural system to adapt to climate change. In addition, the redevelopment of the territory will be aimed at as part of the containment of soil consumption and the mitigation of hydrogeological and seismic risks. Finally, public and private investments will be promoted for the conversion of companies towards sustainable production models, implementing the principles of the bioeconomy and Circular Economy and by encouraging environmental certifications.

The art. 17, on the other hand, defines the damage to the Circular Economy that occurs when the activity leads to significant inefficiencies in the use of materials or in the direct or indirect use of natural resources and when the activity involves a significant increase in the production, incineration or disposal of waste; the long-term disposal of waste could cause significant and long-term damage to the environment.

The part dedicated to research and development describes the fourth area of intervention with the establishment of tax credits for innovative and green investments, also through the promotion of environmental certifications, with particular attention to companies that implement investments aimed at to the transition from a linear to a circular production model (Ministry of economic development, 2020).

Green Economy and Circular Economy are strictly connected in the European policy and the green finance is the logical consequence; the Circular Econo$\mathrm{my}$, mentioned several times in EU acts and defined by the regulation (EU) $\mathrm{n}$. 852/2020, therefore finds an almost identical legal definition in the European Union and in Italy and already has concrete contents on which to measure the objective of the transition to this new development model.

\section{Conclusions}

Despite various insights, uncertainties remain about the most suitable relationship between the environment and the economic activities. Economy, as a traditionally interpretation, has objectively a linear nature, set according to a diachronic model (extract, produce, use, throw). With the environmental crisis (ecological deficit, climate change, pollution, etc.) awareness of the limits of development has progressively grown and, consequently, increasing attention has been devoted to the green economy and finance. Now a further and perhaps more radical passage must be consummated: the green economy is transformed into a "blue economy" (Pauli, 2020), that is into a Circular Econ- 
omy which represents its positive transformation and overcoming, especially in terms of political and industrial culture.

Furthermore, the law of the Circular Economy pushes towards positive, improvement and development policies, while the traditional approach of environmental law was more of a negative nature: from legislation that had the objective of avoiding waste, pollution, climate-changing emissions, we move on to legislation in which positive objectives are accentuated (for example, the promotion of the production of goods that can serve to fertilize or reduce $\mathrm{Co} 2$ ).

The ongoing process, aimed at defining the operational models of the Circular Economy and its legal status as adequate public regulatory approach, starts with the awareness of the insufficiency of market forces to carry out and govern autonomously desired change for a new paradigm and of the importance that environmental administrative law and economics law is increasingly destined to assume.

The Circular Economy imposes the redefinition of the role of public authorities, the relationship between local authorities and utilities companies between these entities and users; this new context could lead to the creation of a real "circular State model", which would go alongside the traditional notions of State liberal or welfare State (Cocconi, 2020; Gusmerotti et al., 2020; Creazza et al., 2020; Cocconi, 2019; Scotti, 2019; Frodermann, 2018; Magri, 2018; Picozza et al., 2019; De Leonardis, 2017; Murray et al., 2017).

Transition and related measures involve very complex issues that cannot be resolved in the medium term, as it necessarily requires new European disciplines and national legislative innovations (the Italian system is certainly not adequate because of slowly, complex not incisive reforms especially for public administration), EU funding and an innovative strategy for internal industrial policy.

The "transition" must be co-managed, precisely in the public services sector involving resources that are commons, through interaction between companies (private and public-private entities), local authorities, users. It is necessary to spread the dialogue between the stakeholders to connect territorial and commercial strategies for the benefit of citizens, in order to create qualified communities with sustainable economies and promote shared results. So, the Circular Economy seems to be an excellent model for the protection and enhancement of common goods through technological and cultural innovation.

The environmental and social responsibility of a company can be oriented towards the production of a "shared value" by winning the engagement of customers and citizens. The main tool is the constant and punctual public communication of projects and results, essential to solicit the attention and sharing aimed at the necessary change expected by society and the environment. In this way, the value in a broad sense, not only economic, of activities and services is shared and goes beyond the traditional scheme of roles.

Furthermore, the most suitable scheme for the management of local public services sector is the public (local authorities, communities, citizens) - private 
(private and mixed enterprises) partnership model, in the sense of extensive collaboration and not only with reference to the legal instruments and to public-private partnership in a technical sense. This scheme is already operational in some areas and needs to be improved for a collaborative governance including the local authorities, public utilities companies, citizens-users and interventions of the regulator.

Consequently, a new institutional subsidiarity is affirmed in a new economic and social context in which public entities and individuals face many challenges related to the environment to search for new solutions on climate changes through relations between national, regional, European levels and private sector. The public-private partnerships should develop new skills and sustainable solutions through territorial and financing strategies to improve actions, financial arrangements and incentives to adapt public services and private or mixed enterprises to low-carbon production.

It is in this context that the question of public authority intervention in economic activities comes into play, in order to understand whether it is possible to discern any coherent design for guiding industry in recent years. The overcoming of the interventionist State model certainly did not entail a complete waiver of the exercise of public powers. However, relations between State and industry are characterised above all by frequent requests for intervention by this sector for a clear Government orientation as basis for industrial enterprise plans; in addition, heterogeneous and uncoordinated actions are due to the constant difficulty of pursuing an overall plan of strategic management of industrial development and forecasting of public initiatives even in the medium period. This situation also applies to the utilities industry.

In practice, the highly critical issue is the public regulation of conditions for industry exercise, given that public power mainly regulates and promotes productive activities through various instruments and occasional interventions without assuming a leading role. Obviously, this scheme is under discussion and urgently needs to be innovated in the current health and economic crisis with a view to implementing the Circular Economy, which implies a decisive commitment of the public authorities. This intricate and gradual path requires adequate economic and technical resources, a clear internal political direction without ambiguity in implementing European policy and a stable discipline based on legal certainty.

In conclusion, the answers that can be outlined, in the face of the various issues raised here, consist in the need to innovate the regulation of the competences and resources of local and regional authorities - whose communities are the users of public services of general economic interest - in order to allow rapid adaptations to the objectives of the Circular Economy and to rethink - without prejudice to the profit motive (which is necessary in business activities) - the important role of public services management companies (through concessions granted by local authorities and their shareholding in companies), precisely because they are technically capable of implementing principles and strategies more efficiently. In addition, it is essential to adopt 
collaborative solutions with citizen-users in order to adopt shared choices that are useful for their needs.

This collaboration must relate to local authorities, public service management companies and users, going beyond the traditional pattern of often conflicting public-private interests.

The future direction of further interesting research will certainly consist in the in-depth study of necessary legal innovations for public bodies and companies, as well as of company statutes and business plans for the most appropriate strategies aimed at implementing the Circular Economy. Finally, a research with a cultural and humanistic nature could aim at better communication and understanding of the Circular Economy (obviously connected to the Green Economy) content and it will be very crucial, in order to foster the informed cooperation of users. 


\section{References}

Antoniazzi, S. (2017). Smart City: quadro generale di atti, programmi e competenze di livello sovranazionale, nazionale e locale. In G. F. Ferrari, (a cura di), La prossima città, Milano: Mimesis, pp. 479 ff.

Antoniazzi, S. (2017). Società miste e servizi pubblici locali, Esperienze nazionali e modello europeo. Napoli: Editoriale Scientifica.

Antoniazzi, S. (2018). Smart City nell'esperienza italiana: l'intreccio di riferimenti normativi, di competenze degli enti territoriali e il ruolo delle società di gestione di servizi pubblici. In V. Aguado et al., eds., El derecho a la ciudad: el reto de las smart cities. Barcelona: Atelier, pp. $171 \mathrm{ff}$.

Antoniazzi, S. (22 May 2019). Smart city: inquadramento giuridico, evoluzione e gestione dei servizi pubblici locali. Federalismi.it, 10.

ARERA (2018). the "Autorità per l'energia elettrica, il gas e il Sistema idrico", an independent administrative authority established by the law n. 481/1995, named "Autorità di regolazione per energia, reti e ambiente (Arera)" after the law n. 205 of December 27, 2017, which assigned functions of regulation and control of the waste cycle, including differentiated, urban and assimilated waste.

ARERA - ANSA (2020). Venticinque. Milano: Arera. At <www.arera.it>.

Aronoff, K. et al. (2019). A Planet to Win: Why we need a Green New Deal, London: Verso Books.

Atil Asici, A. and Bunuzul, Z. (2012). Green New Deal, A Green Way out of the Crisis? Environmental Policy and Governance, 22, pp. 295 ff.

Averardi, A. (2018). Potere pubblico e politiche industriali. Napoli: Jovene Editore.

Barbier, E.B. (2010). Global Governance, The G20 and a Global Green New Deal. Economics, 2, pp. $1 \mathrm{ff}$.

Barbier, E.B. (2019). How to make the next Green New Deal work. Nature, 565, p. 6.

Bianchi, D. (ed.) (2018). Economia circolare in Italia, La filiera del riciclo asse portante di un'economia senza rifiuti. Milano: Edizioni Ambiente.

Bombardelli, M. (ed.) (2016). Prendersi cura dei beni comuni per uscire dalla crisi, Nuove risorse e nuovi modelli di amministrazione. Napoli: Editoriale Scientifica.

Bompan, E. and Brambilla, I.N. (2018). What is Circular Economy. Milano: Edizioni Ambiente.

Bruti Liberati, E. and Donati, F. (ed.) (2010). La regolazione dei servizi di interesse economico generale. Torino: Giappichelli.

Cartei, G.F. (ed.) (2013). Cambiamento climatico e sviluppo sostenibile. Torino: Giappichelli.

Cassese, S. (ed.) (2020). La nuova Costituzione economica. Bari, Roma: Laterza.

Cerrina Feroni, G. (ed.) (2014). Produzione, gestione, smaltimento dei rifiuti in Italia, Francia e Germania tra diritto, tecnologia, politica. Torino: Giappichelli.

Cocconi, M. (2019). Un diritto per l'economia circolare. Il diritto dell'economia, pp. $113 \mathrm{ff}$. At <www.ildirittodell'economia>.

Cocconi, M. (2020). La regolazione dell'economia circolare. Sostenibilità e nuovi paradigmi di sviluppo. Milano: Franco Angeli. 
Coffman, D' M. et al. (2020). Ecological Transition. In F. Cerniglia, F. Saraceno (eds.), A European Public Investment Outlook. Cambridge: Open Book Publishers, pp. $163 \mathrm{ff}$.

Creazza, A., Pizzurno, E., and Urbinati, A. (eds.) (2020). Economia circolare e management, Un nuovo approccio industriale per la gestione d'impresa. Milano: Guerini next.

De Leonardis, F. (2017). Economia circolare: saggio sui suoi tre diversi aspetti giuridici. Verso uno Stato circolare?. Diritto amministrativo, pp. $163 \mathrm{ff}$.

Directive EU (1994-2006): on waste (2008/98/EC) and the special directives on packaging waste (1994/62 /EC), landfills (1999/31/EC), waste electrical and electronic equipment, so-called WEEE (2012/19/EU), end-of-life vehicles (2000/53/EC) and waste batteries and accumulators (2006/66/EC). At <www. eur-lex.europa.eu>.

Durano, G. (2018). Poteri autoritativi tra interessi pubblici e regole del mercato, Alla continua ricerca degli equilibri comunitari. Torino: Giappichelli.

ECB, "Greening the financial system", 2 December 2019. At <www.ecb.europa. eu>.

European Commission. (2019). COM (2019) 22, 30 January 2019; "Report on the implementation of the Circular Economy Action Plan", 4 March 2019, COM (2019) 190 final. At <www.ec.europa.eus and <www.circulareconomy. europa.eu>; "The Circularity Gap Report" 2018, 2019 and 2020. At <www. circle-economy.com>.

European Commission $(2019,2020)$. Communication from the Commission to the European Parliament, the Council, the European Economic and Social Committee and the Committee of the Regions, 27 May 2020, COM (2020) 440 final, Adjusted Commission Work Program and Annexes 1 and 2; The Just Transition Mechanism (Commission proposes a public loan facility to support green investments together with the European Investment Bank, 28 May 2020); Communication COM/2020/98: A new Circular Economy Action Plan for a cleaner and more competitive Europe; Final Circular Economy Package; Proposal (COM(2020)0080, Report 22 September 2020) for a regulation of the European Parliament and of the Council establishing the framework for achieving climate neutrality and amending Regulation (EU) 2018/1999 (European Climate Law); Communication COM/2019/640 from the Commission to the European Parliament, the Council, the European Economic and Social Committee and the Committee of the Regions, The European Green Deal, 11 December 2019. At <www.ec.europa.eu>.

European Commission, 14 January 2020: Green Deal and Just Transition Mechanism Investment Plan; March 4, 2020: Proposal for a European climate law to ensure a climate-neutral European Union by 2050; March 8, 2020: Action plan to finance sustainable growth; March 10: A new industrial strategy for Europe; 11 March 2020: A new action plan for the Circular Economy. For a cleaner and more competitive Europe; 20 May 2020: EU Biodiversity Strategy for 2030. Bringing nature back into our lives; May 20, 2020: A "From producer to consumer" strategy for a fair, healthy and environmentally friendly food system; June 18, 2020, Regulation (EU) 2020/852 of the European Parliament and of the Council on the so-called taxonomy of sustainable finance; 8 July 2020, Adoption of EU strategies for the integration of energy systems and for hydrogen; 17 September 2020, Presentation of the 2030 climate goals plan. At <www.ec.europa.eu>. 
Favaro T. (2019). Dai brownfields alle Smart Cities. Rigenerazione urbana e programmazioni digitalmente orientate. In M. Passalacqua and B. Pozzo (eds.), Diritto e rigenerazione dei brownfields. Torino: Giappichelli, pp. $169 \mathrm{ff}$.

Felber, C. (2012). L'economia del bene comune, Un modello economico che ha futuro. Milano: Tecniche nuove, pp. 17 ff.; for the original edition: Felber, C. (2010 and 2012). Die Gemeinwohl-Ökonomie, Wien: Deuticke im Paul Zsolnay verlag.

Franchini, C. (2020). La disciplina pubblica dell'economia tra diritto nazionale diritto europeo e diritto globale. Napoli: Editoriale Scientifica.

Frodermann L. (2018). Exploratory study on Circular Economy approaches, A comparative analysis of theory exploitation. Berlin: Springer.

Galliani, A. (2020). Innovazioni necessarie per consentire la diffusione delle fonti rinnovabili per la produzione di energia elettrica nel rispetto degli obiettivi europei. In G. D. Comporti and S. Lucattini (eds.). Orizzonti del diritto dell'energia. Innovazione tecnologica, blockchain e fonti rinnovabili. Napoli: Editoriale Scientifica, pp. $153 \mathrm{ff}$.

Gaspari, F. (2018). Smart City, Agenda urbana multilivello e nuova cittadinanza amministrativa. Napoli: Editoriale Scientifica.

Gusmerotti, N.M., Frey, M., and Iraldo, F. (2020). Management dell'economia circolare, Principi, drivers, modelli di business e misurazione. Milano: F. Angeli.

Italian Presidency of the Council of Ministers. (2017). Italian Bioeconomy Strategy. At <www.gov.it>.

Lacy, P. (2015). Waste to wealth, The Circular Economy Advantage. London: Palgrave Macmillan.

Lacy, P. (2016). Circular economy, Dallo spreco al valore. Milano: Egea.

Luisio, F. (2020). I sistemi di incentivazione della produzione di energia elettrica da fonte rinnovabile. Una valutazione critica dei diversi modelli disponibili e sperimentati. In G. D. Comporti and S. Lucattini (a cura di). Orizzonti del diritto dell'energia. Innovazione tecnologica, blockchain e fonti rinnovabili. Napoli: Editoriale Scientifica, pp. $143 \mathrm{ff}$.

Magri, M. (2018). Regioni ed economia circolare. Giornale di diritto amministrativo, pp. $706 \mathrm{ff}$.

Massarutto, A. (2019). Un mondo senza rifiuti? Viaggio nell'economia circolare. Bologna: il Mulino.

Maugeri, M. R. (2020). Smart contracts, smart grids e smart metres: i nuovi orizzonti nel mercato dell'energia e la tutela del consumatore/prosumer. In G. D. Comporti and S. Lucattini, eds., Orizzonti del diritto dell'energia. Innovazione tecnologica, blockchain e fonti rinnovabili. Napoli: Editoriale Scientifica, pp. $13 \mathrm{ff}$.

Mc Arthur Ellen Foundation, Financing the Circular Economy, Capturing the Opportunity, 10 September 2020, pp. 20 ff., 34, 41 ff.; The Circular Economy: a transformative Covid-19 recovery strategy, 27 October 2020. At <www. ellenmcarthurfoundation.org>.

Merusi, F. (2013). Il sogno di Diocleziano. Il diritto nelle crisi economiche. Torino: Giappichelli, pp. 83 ff.

Merusi, F. and Antoniazzi, S. (eds.) (2017). Vent'anni di regolazione accentrata di servizi pubblici locali. Torino: Giappichelli. 
Ministerial Decree 11 giugno 2020. Progetti di ricerca e sviluppo per l'economia circolare. At <www.mise.gov.it>; in <www.gov.it $>$ and <www. politicheeuropee.gov.it>

Munari, F. (2019). L'economia circolare e le nuove regole dell'Unione europea sui rifiuti. Studi sull'integrazione europea, 1, pp. $77 \mathrm{ff}$.

Murray, A., Skene, K., and Kaynes, K. (2017). The Circular Economy, An Interdisciplinary Exploration of the Concept and Application in a Global Context. Journal of Business Ethics, 140, pp. $369 \mathrm{ff}$.

Ostrom, E. (2015). Governing the Commons: The Evolution of Institutions for Collective Action. Cambridge: Cambridge University Press.

Passalacqua, M. (2019). Politiche pubbliche e strumenti giuridici per rigenerazione e riuso di aree industriali dismesse. In M. Passalacqua and B. Pozzo, eds., Diritto e rigenerazione dei brownfields, Amministrazione, obblighi civilistici, tutele. Torino: Giappichelli, pp. $13 \mathrm{ff}$.

Passalacqua, M. (29 giugno 2015). Economia del bene comune e gestione dei servizi di pubblica utilità. At <www.labsus.org>.

Pauli, G. (2020). Blue Economy 3.0. Milano: Edizioni Ambiente.

Pavani G. et al. (2019). Politiche e strumenti per le città collaborative. Istituzioni del Federalismo, 4.

Picozza, E. et al. (2019). Le politiche di programmazione per la resilienza dei sistemi infrastrutturali. Economia circolare, governo del territorio e sostenibilità energetica Torino: Giappichelli.

Scarpellino, S. (2018). La parabola dei rifiuti, Da problema e risorsa, La sfida dell'economia circolare. Roma: Aracne.

Scotti, E. (2019). Poteri pubblici, sviluppo sostenibile ed economia circolare. Il diritto dell'economia, pp. $493 \mathrm{ff}$. At <www.ildirittodell'economia.it>.

Simonati, A. (2018). The (Draft) European Charter of the Commons - Between Opportunities and Challenges. Central European Public Administration Review, pp. 91 ff., https://doi.org/10.17573/сераr.2018.2.05.

Simone, A. (2019). L'economia circolare non è il riciclo. Rivista giuridica ambiente, pp. $671 \mathrm{fF}$.

Tirole, J. (2017). Economia del bene comune. Milano: Mondadori, pp. $213 \mathrm{ff}$.

Venier, S. (2018). Il Turning Point dello sviluppo sostenibile. In www.astrolabio. amicidellaterra.it.

Venier, S. (2018). Gli effetti della trasformazione tecnologica sui sistemi industriali. Harvard Business Review, pp. $74 \mathrm{ff}$.

Venier S. and Lucatti E. (2018). Future Hall. Le Circular Smart City come driver globali di uno sviluppo sostenibile e resiliente. In V. Aguado et al., eds., El derecho a la ciudad: el reto de las smart cities. Barcelona: Atelier, pp. $191 \mathrm{ff}$.

Venier, S. and Bocchi, F. M. (2019). Misurare il valore condiviso: l'evoluzione necessaria nel reporting delle imprese. Harvard Business Review, pp. 70 ff.

Venier, S. (28 May 2020). Non sacrificare l'economia circolare sull'altare della ripresa economica. At <www.rivistaenergia.it>.

Venier, S. and Verde, S. (2020). Hera Group: The Path Towards Shared Value and Circularity. In A. Gilardoni, ed., The Italian Utilities Industry. Berlin: Springer, pp. $139 \mathrm{ff}$.

Venier, S. (2021). Dare acqua al domani. At <www.astrolabio.amicidellaterra.it>. 
Verri, P. (2019). Il regime autorizzatorio "end of waste", tra dato normativo e legittime tensioni verso la "Circular Economy". Rivista giuridica ambiente, pp. $171 \mathrm{fF}$.

Zanchini, E. and Albrizio, M. (eds.) (2019). Un green deal per l'Europa, Le idee e le sfide per rilanciare il progetto europeo, Rapporto annuale di Legambiente. Milano: Edizioni Ambiente. 